\title{
A subgroup of microsatellite stable colorectal cancers has elevated mutation rates and different responses to alkylating and oxidising
} agents

\author{
AR Parker',3, CP Leonard ',3, L Hua', RO Francis', S Dhara', A Maitra' ${ }^{1,2}$ and JR Eshleman ${ }^{*, 1,2}$ \\ 'Department of Pathology, Johns Hopkins University, Baltimore, MD 21 205, USA; ²Department of Oncology, Johns Hopkins University, Baltimore, MD \\ 21205, USA
}

An early step in the carcinogenesis of hereditary non-polyposis colorectal cancer (HNPCC) and some sporadic colorectal cancers (CRCs) is the acquisition of a 'mutator phenotype' resulting from defects in DNA mismatch repair (MMR) genes, which normally maintain genomic stability. This mutator phenotype causes an approximately 100-1000-fold increase in base substitutions and small insertion/deletion mutations thereby driving carcinogenesis. It also causes genome-wide microsatellite instability (MSI) due to the inability to repair mutations within these small, hard to replicate, repetitive DNA elements. In contrast, less is known about the role of mutator phenotypes in microsatellite stable (MSS) CRC. In this report, we have measured the mutation rates in II MSS CRC cell lines to obtain an estimate of the prevalence of mutator phenotypes in MSS carcinogenesis. Of the I I cell lines, three of them (27\%) possess spontaneous hypoxanthine phosphoribosyltransferase mutation rates approximately $10-100$-fold above background. When challenged with alkylating and oxidising agents, the degree of survival and apoptotic responses are different, indicating that these cell lines may represent more than one mutator phenotype. These data demonstrate that a significant portion of MSS CRC cell lines has increased mutation rates and that this may play a role in MSS CRC carcinogenesis.

British Journal of Cancer (2004) 90, 1666-167I. doi:I0.1038/sj.bjc.6601740 www.bjcancer.com

Published online 16 March 2004

(C) 2004 Cancer Research UK

Keywords: microsatellite stable; hprt; mutator phenotypes; 6-thioguanine; colorectal cancer; MSI; MSS

Since the low spontaneous mutation rate in normal cells is difficult to reconcile with the relatively large number of mutations observed in tumours (Fearon and Vogelstein, 1990), Loeb and Nowell have proposed that early in multistep carcinogenesis, cells first acquire a 'mutator phenotype' (Nowell, 1976; Loeb, 1991, 2001). Because of their increased mutation rates, cells with mutator phenotypes can produce requisite numbers of mutations in oncogenes and tumour suppressor genes, which are subsequently selected for and manifested in the final tumour (Nowell, 1976; Fearon and Vogelstein, 1990). Mutator phenotypes should therefore be thought of as carcinogenic because they accelerate mutation production during tumorigenesis. The same oncogenes and tumour suppressor genes that are mutated in the spontaneous pathway may be similarly involved in mutator phenotype pathways although the spectrum of mutations may be somewhat different (Lipton et al, 2003).

The hypothesis of the role for mutator phenotypes in tumorigenesis is supported by several human genetic disorders where mutations in genome caretaker genes have been shown to

*Correspondence: Dr JR Eshleman, Department of Pathology, The Johns Hopkins University School of Medicine, 720 Rutland Avenue, 632 Ross Building, Baltimore, MD 2 1205, USA. E-mail: jeshlema@jhmi.edu

${ }^{3}$ These authors contributed equally to this work.

Received 4 August 2003; revised 9 January 2004; accepted 2 February 2004; published online 16 March 2004 both elevate the cell's mutation rate and predispose to neoplasia. For example, xeroderma pigmentosum $(\mathrm{XP})^{4}$ patients possess inherited defects in nucleotide excision repair (NER) and a predilection to skin cancer, and the mutation rate is significantly elevated in their cells when exposed to UV light (Maher et al, 1979). Cells from hereditary non-polyposis colorectal cancer (HNPCC) associated cancers and sporadic colorectal cancer (CRCs), possess a mutator phenotype that arises from genetic or epigenetic defects in the DNA mismatch repair (MMR) system (Fishel et al, 1993; Leach et al, 1993; Kane et al, 1997; Veigl et al, 1998). This mutator phenotype increases the spontaneous rates of base substitution and small insertion/deletion mutations approximately 100-1000-fold (Bhattacharyya et al, 1994, 1995; Eshleman et al, 1995, 1996) and provides a plausible explanation for the high rate of carcinogenesis observed.

We hypothesised that mutator phenotypes might occur commonly in microsatellite stable (MSS) CRC carcinogenesis and to test this, we screened a panel of MSS CRC cell lines. To test this hypothesis, we employed the classic selectable mutation marker for human studies, hypoxanthine phosphoribosyltransferase (HPRT). We report here that three out of $11(3 / 11,27 \%)$ MSS CRC cell lines tested possess elevated HPRT mutation rates. The MSS CRC cell lines with elevated mutation rates demonstrate unique patterns of sensitivity to the cytotoxic chemicals $N$-methyl- $N^{\prime}$-nitro- $N$-nitrosoguanidine (MNNG) and hydrogen peroxide $\left(\mathrm{H}_{2} \mathrm{O}_{2}\right)$. They are at least in part independent of the recently reported MutY mutations (Al-Tassan et al, 2002; Sieber et al, 2003). We propose that mutator 
phenotypes are common in MSS CRC, are likely more than one type, and may play an important role in MSS CRC carcinogenesis.

\section{MATERIALS AND METHODS}

\section{Cell lines}

The MSS CRC cell lines were either isolated and generously provided by Dr James KV Willson (Case Western Reserve University, those with Vaco prefixes) or purchased from the ATCC. Other than there being microsatellite stable, there were no other criteria for selecting these cell lines. One cell line was excluded because it had a low cloning efficiency.

\section{Cell culture, initial selection of 6-thioguanine (6TG) resistant mutants, and fluctuation analysis}

Cells were grown and selected in 6TG (Sigma, St Louis, MO, USA) as published previously (Willson et al, 1987; Eshleman et al, 1995). Briefly, after subculturing, cells were counted and plated in 96-well plates to determine the cloning efficiency (CE) and at 10000 cells per well in $1.5-5 \mu \mathrm{g} \mathrm{ml}^{-1} 6 \mathrm{TG}$ to test for mutations. Plates were fed every 2 weeks and wells scored positive for growth by phase microscopy after 6 weeks. This was repeated until approximately 30 million clonogenic units had been analysed (three of the cell lines from the series, SW837, Vaco489 and Vaco576, have been preliminarily analysed, but with only approximately 5 million clonogenic units (Eshleman et al, 1995)).

Cell lines exhibiting mutations in the initial screen were examined using fluctuation analysis as previously described (Luria, 1943; Eshleman et al, 1995). Briefly, cells were purged of pre-existing mutants by dilution and regrowth from 100 cells in 10 replicate cultures. These cultures were independently expanded to approximately 10-30 million cells and plated for cloning efficiency and mutation frequency as described.

\section{Determination of cloning efficiency and calculation of mutation rates and frequencies}

CE was determined by seeding three and 10 cells per well in 96-well plates in the presence of SW480 or native feeder cells lethally irradiated with 8000 centi-Gy ${ }^{137} \mathrm{Cs}$ at a concentration of 10000 cells per well. CE was calculated using Poisson statistics as described previously (Furth et al, 1981), where CE $=[-\ln$ (fraction of negative wells)]/(number of cells seeded per well). The CE for each cell line presented in Table 1 is expressed as the mean for all replicate cultures of that line. Mutation frequency (MF) and mutation rate (MR) calculations were performed essentially as described (Eshleman et al, 1995). Briefly, mutation rates were calculated using Poisson corrected counts (Furth et al, 1981) and the tables of Capizzi and Jameson (Capizzi and Jameson, 1973). For cell lines lacking mutations, mutation frequencies and rates were calculated assuming that one hypothetical mutant had been isolated and expressed as less than that value.

\section{Microsatellite analysis}

To test for microsatellite instability, cells were plated at $1-3$ cells per well, in 96-well plates, and expanded. In total, 10 independent clones, per cell line, were analysed for microsatellite length using the five nucleotide repeats recommended at the NCI-sponsored conference on microsatellite instability (MSI) for CRC (Boland et al, 1998) BAT25, BAT26, D5S346, D2S123 and D17S250 using multiplex PCR and capillary electrophoresis (Berg et al, 2000).

\section{hprt cDNA sequencing}

To confirm the presence of mutations, RNA from 6TG resistant colonies was isolated using the RNAgents Total RNA Isolation System (Promega, Madison, WI, USA). The isolated RNA (approximately $500 \mathrm{ng}$ ) was reverse-transcribed using $5 \mathrm{U}$ AMV reverse transcriptase (Boehringer Mannheim, Mannheim, Germany) in a $20 \mu \mathrm{l}$ buffered solution with $20 \mathrm{U}$ of RNasin (Promega), $0.5 \mu \mathrm{g}$ of Oligo $(\mathrm{dT})_{12-18}$ primer (GIBCO, Grand Island, NY, USA), and $20 \mathrm{~mm}$ of dNTPs. After the incubation, $5 \mu \mathrm{M}$ of M13 tailed forward sense primer S-27 ( -27 to -12 relative to the AUG) $5^{\prime}$ GTAAAACGACGGCCAG-TCAGCCCGCGCGCCGGC- $3^{\prime}, \quad 5 \mu \mathrm{m}$ of M13 tailed reverse primer AS661 (661-557) 5'-CAGGAAACAGCTATGAC-TCAACTTGAACTCTC- $3^{\prime}$ and $1 \mu$ l of template DNA were added to the Taq PCR Master Mix (Qiagen, Valencia, CA, USA) and incubated for $10 \mathrm{~min}$ at $94^{\circ} \mathrm{C}$. The cDNA was amplified for a total of 30 cycles with each cycle consisting of $1 \mathrm{~min}$ at $94^{\circ} \mathrm{C}, 1 \mathrm{~min}$ at $60^{\circ} \mathrm{C}$ and $3 \mathrm{~min}$ at $72^{\circ} \mathrm{C}$. Final extension of the PCR amplified product was for $10 \mathrm{~min}$ at $72^{\circ} \mathrm{C}$. PCR amplified samples were sequenced using M13 primers and Big Dye cycle sequencing on an ABI3700 sequencer (Applied Biosystems, Foster City, CA, USA).

\section{Cell viability after treatment with $N$-methyl- $N^{\prime}$-nitro- $N$ - nitrosoguanidine (MNNG) and hydrogen peroxide $\left(\mathrm{H}_{2} \mathrm{O}_{2}\right)$}

For the cell viability assay, exponentially growing cells were trypsinised and washed twice in serum-free minimal essential medium (SF-MEM). Washed cells were suspended in SF-MEM and treated with $0-5 \mu \mathrm{M}$ MNNG (Sigma) for $45 \mathrm{~min}$ at $37^{\circ} \mathrm{C}$ or with

Table I Mutation frequencies and mutation rates of MSS CRC lines

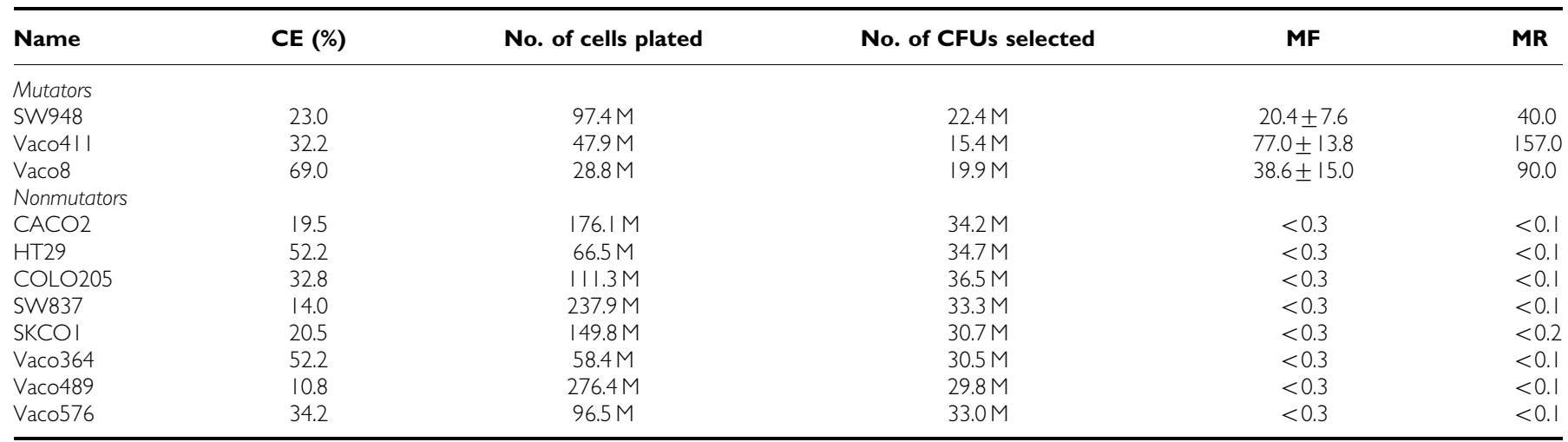

$\mathrm{CE}=$ cloning efficiency; $\mathrm{CFU}=$ colony-forming units; $\mathrm{MF}=$ mutation frequency; $\mathrm{MR}=$ mutation rate. The CE for each cell line presented here is expressed as the mean for all replicate cultures of that line. No. of CFUs selected is the total number of CFUs plated into 6TG for assay of HPRT mutants. M $=10^{6}$. Mutation frequencies are expressed as $10^{-7}$ mutants per CFU. Mutation rates are expressed as $10^{-8}$ mutations per locus per generation (Eshleman et al, 1995). 
$0-300 \mu \mathrm{M} \mathrm{H} \mathrm{H}_{2} \mathrm{O}_{2}$ (Sigma) for $60 \mathrm{~min}$ at $37^{\circ} \mathrm{C}$. After treatment, the cells were washed once with MEM2 + media (Willson et al, 1987), resuspended in fresh growth medium, and seeded (approximately 500000 cells well $^{-1}$ (200000 for Vaco8) in six-well plates. The cells were grown for 5 days (for $\mathrm{H}_{2} \mathrm{O}_{2}$ ) or 6 days (for $\mathrm{MNNG}$ ), subcultured and counted using trypan blue exclusion with a haemocytometer. Experiments were performed three times, each in triplicate.

\section{Assessment of apoptotic response}

Apoptosis was assessed after treating cells with either_5 $\mu \mathrm{M}$ MNNG or $300 \mu \mathrm{M} \mathrm{H}_{2} \mathrm{O}_{2}$ as described above, and monitoring the cells at various time points after treatment. Apoptosis was determined as described (Wang et al, 1995) using DAPI as the vital dye and propidium iodide as the excluded dye. Briefly, cells were washed at various times after treatment and stained in MEM with $112 \mu \mathrm{g} \mathrm{ml}^{-1}$ DAPI (Sigma) for $10 \mathrm{~min}$, followed by $60 \mu \mathrm{g} \mathrm{ml}^{-1}$ propidium iodide (Sigma) and fluorescence microscopy. In all, 200 cells were counted and the percent of cells that demonstrated apoptotic bodies calculated.

\section{RESULTS}

\section{Three out of 11 MSS CRC cell lines possess elevated HPRT mutation rates}

We measured the spontaneous HPRT mutation rate in 11 MSS CRC cell lines (Table 1, and Figure 1). For initial screening, these cell lines were expanded and plated in the presence of 6TG, until approximately 30 million colony-forming units (CFUs) had been tested for 6TG resistance. Since many of the cell lines displayed no mutants, we estimated the rate using a single hypothetical mutant. The mutation rates of eight of the MSS CRC cell lines were $<0.1$ $0.2 \times 10^{-8}$ mutations per locus per cell division (Table 1) and defined the baseline level of spontaneous mutation. We previously reported a limited analysis of three of the nonmutator cell lines (Eshleman et al, 1995), that we have analysed to a much greater degree in the present study. To obtain the best estimate of the overall prevalence of elevated mutation rates in MSS CRC, we included the previously identified MSS CRC cell line Vaco411, since it was part of an original series of sequential cell lines expanded and examined in more detail in this report (Eshleman

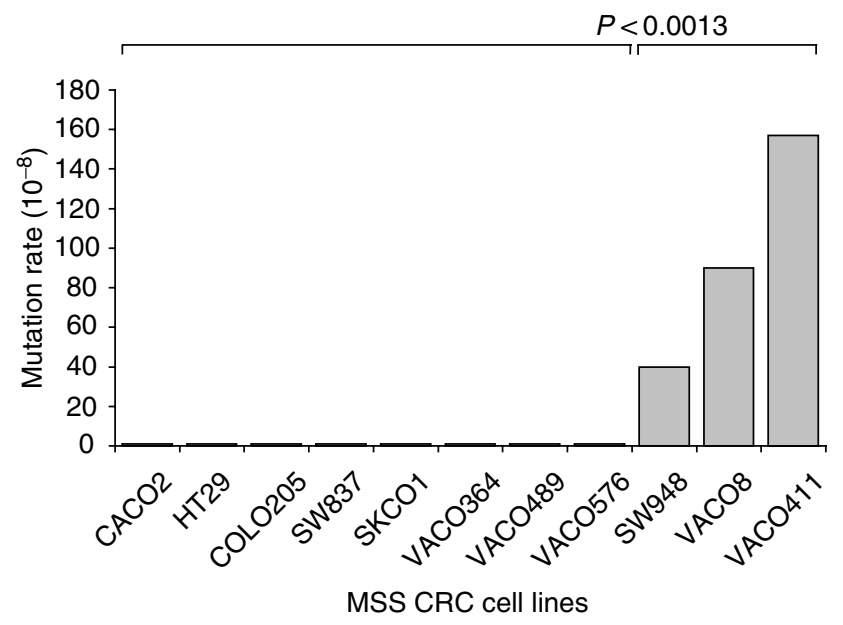

Figure I Mutation rates of the MSS CRC cell lines Vaco8, Vaco4II and SW948 are increased. Mutation rates in the II MSS CRC cell lines as described. The mutators were compared to the nonmutators using the unpaired Student's t-test. et al, 1998). During the initial screen in 6TG, while most of the cell lines yielded no HPRT mutants (Table 1, Figure 1), three cell lines possessed an elevated mutation rate (approximately 100 -fold above background nonmutator cell lines). Statistical analysis confirmed that the elevated mutation rates in these three MSS CRC cell lines are significantly different from the baseline mutation rates in the nonmutator CRC cell lines $(P=0.0013$, unpaired $t$-test). Furthermore, the mutation frequency of one of them (Vaco411) appears to be higher than the other two. Limited sequencing of the hprt cDNA (Eshleman et al, 1996) from several mutants from each of the cell lines exhibiting 6TG resistance confirmed that mutations within $h p r t$ were indeed present (manuscript in preparation). The ages of the patients when the tumours were diagnosed were 32, 56 and 81 years old for Vaco411, Vaco8 and SW948, respectively.

\section{The MSS CRC cells with elevated mutation rates are} differentially sensitive to alkylation and oxidative chemical challenge

A consistent feature of cells with elevated mutation rates due to defective MMR has been the tolerance to alkylating agents such as MNNG (Branch et al, 1993; Kat et al, 1993). We therefore asked whether the MSS CRC cell lines with mutator phenotypes would be altered in their responses to MNNG. As demonstrated previously (Koi et al, 1994), the MMR deficient cell line, HCT116, was relatively resistant to the cytotoxic effects of MNNG since this cell line carries two defective $m l h 1$ genes (Figure 2A, (Papadopoulos et al, 1994)). In contrast and as expected, the SW480 MMR proficient cell line was sensitive to the cytotoxic effects of MNNG since it possesses a functional MMR system. Of the MMR proficient mutators, Vaco411, was sensitive to MNNG similar to SW480 (approximately $18 \%$ cell viability after treatment with $5 \mu \mathrm{M}$ MNNG), while SW948 and Vaco8 were both intermediate, demonstrating more resistance than both SW480 and Vaco411 but less than HCT116 (compare $18 \%$ of cells remaining after $5 \mu \mathrm{M}$ MNNG, to $39 \%$ for SW948, 50\% for Vaco8 and 75\% for HCT116).

We have previously demonstrated that two of the three mutators have elevated levels of the mutagenic base 8-oxoG (Parker et al, 2002). Since both Vaco411 and Vaco8 possesses low rates of 8oxoG repair and elevated genomic 8-oxoG levels (Parker et al, 2002), we hypothesised that a mutator phenotype, which affects 8oxoG repair, might affect their ability to repair oxidative DNA damage induced by hydrogen peroxide $\left(\mathrm{H}_{2} \mathrm{O}_{2}\right)$. Figure $2 \mathrm{~B}$ shows that both Vaco411 and the MutY proficient cell line SW948 were more resistant towards $\mathrm{H}_{2} \mathrm{O}_{2}$ treatment (41 and $42 \%$ of cells remaining respectively after $300 \mu \mathrm{M} \mathrm{H}_{2} \mathrm{O}_{2}$ ) than the other three cell lines.

Two of the three mutator cell lines undergo apoptotic cell death after chemical challenge

Having demonstrated this differential toxicity, we next asked whether the cell death occurred through apoptosis. We challenged the cell lines with either MNNG or $\mathrm{H}_{2} \mathrm{O}_{2}$ at the highest doses tested above, and monitored the cells for apoptosis after $0,1,2,3$ and $24 \mathrm{~h}$ after treatment. Harvested cells were stained with DAPI and propidium iodide and directly scored for the presence of apoptotic bodies by fluorescence microscopy (see Materials and Methods (Wang et al, 1995)). When challenged with MNNG, two of the mutator cell lines (Vaco411 and SW948) showed significant apoptosis, while the other mutator (Vaco8) and the MMR proficient and deficient controls demonstrated little, if any, apoptosis (Figure 3A). In response to peroxide treatment, the same two mutator lines exhibited apoptosis, although the degree of apoptosis and the timing of it varied from that seen in response to MNNG (Figure 3B). Again, the other three cell lines demonstrated little, if any, apoptosis. 

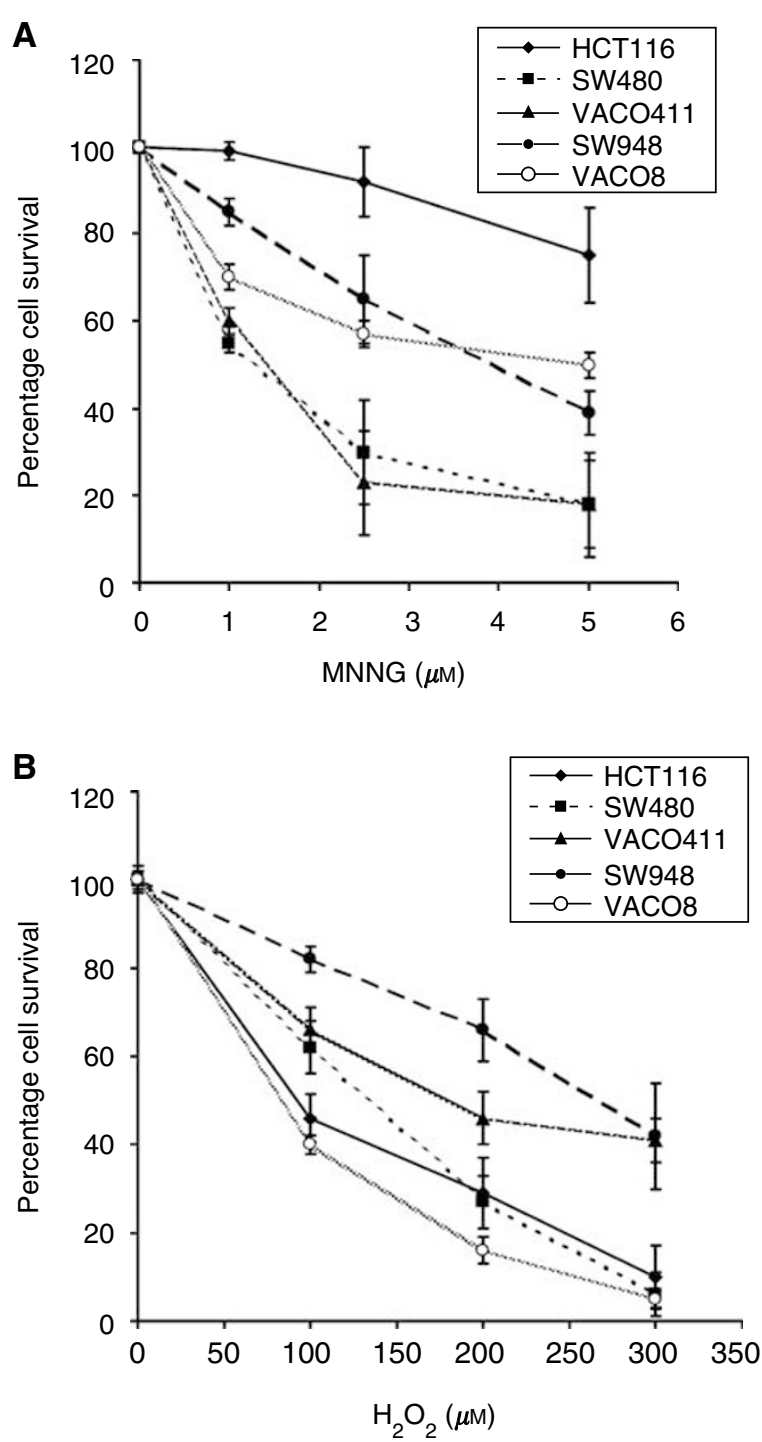

Figure 2 Cell survival following alkylating and oxidative chemical challenge. (A) Vaco8 and SW948, but not Vaco4II, possess intermediate resistance to MNNG. The three MSS mutators and two control cell lines (HCTI I 6, MSI mutator and SW480, MSS nonmutator) were treated with $0-5 \mu \mathrm{M}$ MNNG for $45 \mathrm{~min}$ at $37^{\circ} \mathrm{C}$. The cells were grown for 6 days, subcultured and counted using trypan blue exclusion with a haemocytometer. (B) Vaco4II and SW948, but not Vaco8, possess resistance to $\mathrm{H}_{2} \mathrm{O}_{2}$. The same cell lines were treated with $0-300 \mu \mathrm{M} \mathrm{H} \mathrm{H}_{2} \mathrm{O}_{2}$ for 60 min at $37^{\circ} \mathrm{C}$. The cells were grown for 5 days, subcultured and counted using trypan blue exclusion with a haemocytometer. Experiments were performed three times, each in triplicate and the error bars represent I s.e.m.

\section{The three MSS CRC cell lines with elevated mutation rates are microsatellite stable}

To confirm that the elevated mutation rates were not due to defective MMR activity and that the cell lines possess stable microsatellite DNA, a panel of five microsatellite markers, two mononucleotides and three dinucleotides, were analysed. In all, 10 independently derived clones, from each of the three MSS mutator cell lines and HCT116 as a positive control, were analysed using these five microsatellite markers recommended at a US NCIsponsored conference on MSI for CRC (Boland et al, 1998) BAT25, BAT26, D5S346, D2S123 and D17S250 using multiplex PCR and capillary electrophoresis (Berg et al, 2000). All five loci that were
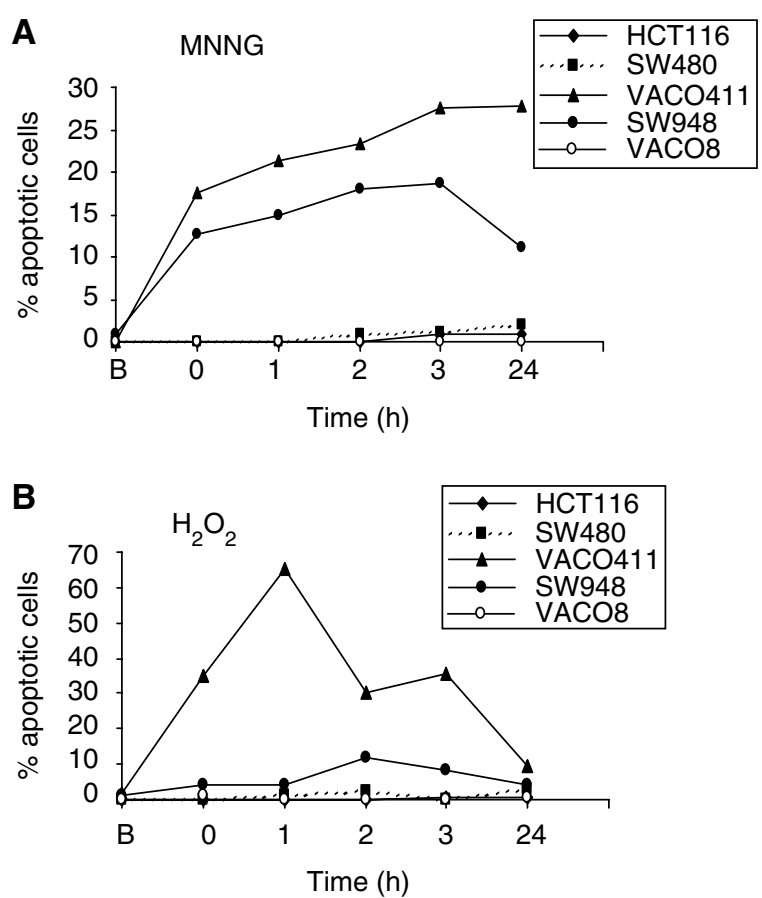

Figure 3 Two of the three MSS mutator cell lines demonstrate apoptotic response to chemical challenge. Apoptotic response after treatment with MNNG $(\mathbf{A})$ or $\mathrm{H}_{2} \mathrm{O}_{2}(\mathbf{B})$. Cells either before $(\mathbf{B})$ or after treatment with the maximal dose of drug, were recovered for various times and the percent of cells undergoing apoptosis determined by nuclear staining (see Materials and methods).

PCR amplified and had stable lengths confirming that Vaco411, Vaco8 and SW948 are microsatellite stable (data not shown) and therefore likely MMR competent. For Vaco411, we have previously reported that its mutation spectrum is inconsistent with an MMR defect and that it is functionally MMR competent when directly challenged with mispaired DNA substrates (Eshleman et al, 1998b).

\section{DISCUSSION}

The current study suggests that mutator phenotypes may play a significant overall role in MSS CRC carcinogenesis since, from a panel of 11 MSS CRC cell lines, three possessed elevated mutation rates $(27 \%)$. The majority (eight out of $11,73 \%$ ) however, showed normal baseline rates.

In MMR-deficient CRC, the spontaneous mutation rates are generally elevated at least 100-1000-fold above the baseline normal rate. In contrast, the increased HPRT mutation rates we report in this current study in the MSS CRC cell lines are approximately 10-100-fold increased relative to control levels in nonmutator MSS CRC cells and accordingly are designated as 'intermediate' elevated levels. It is noteworthy that intermediate mutation rates are present in other diseases such as Bloom's syndrome (approximately 10-fold higher than normal patients) (Warren et al, 1981) and Werner syndrome (10-50-fold higher than normal cell lines) (Fukuchi et al, 1989), and we interpret the intermediate elevated mutation rates observed here as likely biologically significant.

Given the differences in mutation rates, the differential responses to MNNG and $\mathrm{H}_{2} \mathrm{O}_{2}$, and the differences in the levels of genomic 8-oxoG, it seems likely that there is more than one underlying defect responsible for these novel MMR-independent mutator phenotypes. The cell line characteristics from this study are shown in Table 2. Vaco8 possesses elevated levels of genomic 
Table 2 Characteristics of MSS CRC mutator cell lines

Cytotoxic response

\begin{tabular}{|c|c|c|c|c|}
\hline Cell line & Microsatellite status & Mutator defect & $\mathrm{H}_{2} \mathbf{O}_{2}$ & $\mathbf{M N N G}^{\mathbf{a}}$ \\
\hline Vaco8 & MSS & Elevated 8-oxoG & Normal & Int. resistant \\
\hline Vaco4II & MSS & Elevated 8-oxoG & Resistant & Normal \\
\hline SW948 & MSS & Unknown & Resistant & Int. resistant \\
\hline НСТ।I6 & $\mathrm{MSI}$ & $\mathrm{mlhl}$ & Normal & Resistant \\
\hline SW480 & MSS & None & Normal & Normal \\
\hline
\end{tabular}

ant. indicates intermediate.

8-oxoG and low levels of MutY protein which may explain the elevated mutation rate since yeast and Escherichia coli (E.coli) defective in mut $Y$ possess elevated mutation rates approximately 30-fold above the background rate (Nghiem et al, 1988; Chang and $\mathrm{Lu}, 2002)$. However, Vaco8 possessed intermediate resistance to MNNG, but was appropriately sensitive to $\mathrm{H}_{2} \mathrm{O}_{2}$, suggesting instead that repair of alkylated DNA damage may be impaired. A partially impaired MMR system, one which can maintain normal microsatellite length but cannot detect or signal for apoptosis could be responsible, but it is also possible that intermediate level of resistance to MNNG and oxidative damage may be due to defects in another DNA repair system. Recently levels of smad4/ $d p c 4$, a transcription factor frequently lost in pancreatic cancer, have been shown to be defective in this cell line (Fink et al, 2003).

Vaco411, similar to Vaco8, also possesses elevated levels of genomic 8-oxoG and low levels of MutY protein, however this cell line is relatively resistant to $\mathrm{H}_{2} \mathrm{O}_{2}$ and unlike SW948, HCT116 and Vaco8, it was fully sensitive to MNNG suggesting that repair of oxidative DNA damage may be the more important defect. However, the spectrum of mutations in this cell line (Eshleman et al, 1998) is not fully explained by a single defect in MutY (AlTassan et al, 2002; Jones et al, 2002; Sieber et al, 2003), strongly suggesting that a second gene defect may also be present.

SW948, unlike the other four cell lines, is relatively resistant to both $\mathrm{H}_{2} \mathrm{O}_{2}$ and MNNG. The cell viability studies with MNNG suggest that although its MMR system is sufficient to maintain stable microsatellite length, it may not provide fully appropriate sensitivity to the methylating agent MNNG, as previously reported (Claij and Te Riele, 2002) and similar to that suggested for Vaco8 (Table 2). Resistance to oxidative stress, is also potentially consistent with an altered but semifunctional MMR system since msh2-/- (mut S homolog 2) mouse cells contain increased levels of oxidative DNA damage (DeWeese et al, 1998) and MMRdeficient cells can be somewhat resistant to $\mathrm{H}_{2} \mathrm{O}_{2}$ (Glaab et al, 2001). The spectrum of mutations in these novel MSS mutator phenotypes will likely provide insight to identify the genes responsible and comprehensive sequencing of the hprt cDNA from the mutator cell lines is currently underway.

It is interesting that the majority of cell lines (eight out of 11, $73 \%$ ) did not possess elevated $h p r t$ mutation rates. There are three potential possibilities for this: (1) There is a mutator phenotype but it was not detected. This seems unlikely since the HPRT assay detects such a wide range of mutations (Albertini, 2001) (though not changes in chromosome number, see possibility \#3 below).

\section{REFERENCES}

Albertini RJ (2001) HPRT mutations in humans: biomarkers for mechanistic studies. Mutat Res 489: $1-16$

Al-Tassan N, Chmiel NH, Maynard J, Fleming N, Livingston AL, Williams GT, Hodges AK, Davies DR, David SS, Sampson JR, Cheadle JP (2002) Inherited variants of MYH associated with somatic G:C- $>$ T:A mutations in colorectal tumors. Nat Genet 30: 227-232
Further, we have established that when X-ray-induced HPRT mutant cells are spiked into wild-type cells, they are efficiently recovered (Eshleman et al, 1995). (2) There was a functional mutator phenotype expressed in these cells early during carcinogenesis, but it was transient and by the time of diagnosis and resection, the pre-existing mutator phenotype is no longer present, for example, due to transient methylation (Loeb, 2001). (3) Finally, there is in fact no functional mutator phenotype in the majority of MSS CRCs during carcinogenesis. This is consistent with the results of () although the cell lines and assays employed are substantially different.

One problem with possibility \#3 is that most investigators consider genomic instability the fundamental (or at least one fundamental) feature of malignancy, because it explains how malignant cells acquire many of the critical features that distinguish them from their normal counterparts (e.g. ability to metastasise and acquire resistance to chemotherapeutics). One possible explanation is that most of the cell lines without a functional HPRT mutator phenotype manifest the chromosome instability (CIN) phenotype (Lengauer et al, 1997; Eshleman et al, 1998b). Since the CIN phenotype is assayed by centromeric fluorescence in situ hybridisation, it reports for changes in chromosome number whereas the HPRT assay is not expected to detect such changes. However, because CIN (production of aneuploidy) occurs at substantial rates, it can easily produce the second hit in tumour suppressor genes through loss of heterozygosity, and is therefore probably appropriate to consider CIN a mutator phenotype (Cahill et al, 1998).

In conclusion, these data demonstrate that a significant subgroup (approximately one-quarter) of MSS CRCs exist with elevated mutation rates that are likely independent of one another. This suggests that mutator phenotypes may also play a role in MSS CRC carcinogenesis.

\section{ACKNOWLEDGEMENTS}

JRE was supported by Grants R01CA81439 and K08CA66628. We acknowledge Dr James KV Willson (Case Western Reserve University) for generously providing the Vaco cell lines. We thank Drs Sanford Markowitz, Jim Willson, Bert Vogelstein, Victor E Velculescu, Dwight Oliver, Connie Griffin, Laura Morsberger and Anita Hawkins for helpful discussions.
Berg KD, Glaser CL, Thompson RE, Hamilton SR, Griffin CA, Eshleman JR (2000) Detection of microsatellite instability by fluorescence multiplex polymerase chain reaction. J Mol Diagn 2: 20-28

Bhattacharyya NP, Ganesh A, Phear G, Richards B, Skandalis A, Meuth M (1995) Molecular analysis of mutations in mutator colorectal carcinoma cell lines. Hum Mol Genet 4: 2057-2064 
Bhattacharyya NP, Skandalis A, Ganesh A, Groden J, Meuth M (1994) Mutator phenotypes in human colorectal carcinoma cell lines. Proc Natl Acad Sci USA 91: 6319-6323

Boland CR, Thibodeau SN, Hamilton SR, Sidransky D, Eshleman JR, Burt RW, Meltzer SJ, Rodriguez-Bigas MA, Fodde R, Ranzani GN, Srivastava S (1998) A National Cancer Institute Workshop on microsatellite instability for cancer detection and familial predisposition: development of international criteria for the determination of microsatellite instability in colorectal cancer. Cancer Res 58: 5248-5257

Branch P, Aquilina G, Bignami M, Karran P (1993) Defective mismatch binding and a mutator phenotype in cells tolerant to DNA damage. Nature 362: 652-654

Cahill DP, Lengauer C, Yu J, Riggins GJ, Willson JK, Markowitz SD, Kinzler KW, Vogelstein B (1998) Mutations of mitotic checkpoint genes in human cancers. Nature 392: 300-303

Capizzi RL, Jameson JW (1973) A table for the estimation of the spontaneous mutation rate of cells in culture. Mutat Res 17: 147-148

Chang DY, Lu AL (2002) Functional interaction of MutY homolog with proliferating cell nuclear antigen in fission yeast, Schizosaccharomyces pombe. J Biol Chem 277: 11853-11858

Claij N, Te Riele H (2002) Methylation tolerance in mismatch repair proficient cells with low MSH2 protein level. Oncogene 21: 2873-2879

DeWeese TL, Shipman JM, Larrier NA, Buckley NM, Kidd LR, Groopman JD, Cutler RG, te Riele H, Nelson WG (1998) Mouse embryonic stem cells carrying one or two defective Msh2 alleles respond abnormally to oxidative stress inflicted by low-level radiation. Proc Natl Acad Sci USA 95: $11915-11920$

Eshleman JR, Donover PS, Littman SJ, Swinler SE, Li GM, Lutterbaugh JD, Willson JK, Modrich P, Sedwick WD, Markowitz SD, Veigl ML (1998) Increased transversions in a novel mutator colon cancer cell line. Oncogene 16: $1125-1130$

Eshleman JR, Lang EZ, Bowerfind GK, Parsons R, Vogelstein B, Willson JK, Veigl ML, Sedwick WD, Markowitz SD (1995) Increased mutation rate at the hprt locus accompanies microsatellite instability in colon cancer. Oncogene 10: 33-37

Eshleman JR, Markowitz SD, Donover PS, Lang EZ, Lutterbaugh JD, Li GM, Longley M, Modrich P, Veigl ML, Sedwick WD (1996) Diverse hypermutability of multiple expressed sequence motifs present in a cancer with microsatellite instability. Oncogene 12: 1425-1432

Fearon ER, Vogelstein B (1990) A genetic model for colorectal tumorigenesis. Cell 61: 759-767

Fink SP, Mikkola D, Willson JK, Markowitz S (2003) TGF-beta-induced nuclear localization of Smad2 and Smad3 in Smad4 null cancer cell lines. Oncogene 22: $1317-1323$

Fishel R, Lescoe MK, Rao MR, Copeland NG, Jenkins NA, Garber J, Kane M, Kolodner R (1993) The human mutator gene homolog MSH2 and its association with hereditary nonpolyposis colon cancer. Cell 75: $1027-1038$

Fukuchi K, Martin GM, Monnat Jr RJ (1989) Mutator phenotype of Werner syndrome is characterized by extensive deletions. Proc Natl Acad Sci USA 86: $5893-5897$

Furth EE, Thilly WG, Penman BW, Liber HL, Rand WM (1981) Quantitative assay for mutation in diploid human lymphoblasts using microtiter plates. Anal Biochem 110: 1-8

Glaab WE, Hill RB, Skopek TR (2001) Suppression of spontaneous and hydrogen peroxide-induced mutagenesis by the antioxidant ascorbate in mismatch repair-deficient human colon cancer cells. Carcinogenesis 22: $1709-1713$

Jones S, Emmerson P, Maynard J, Best JM, Jordan S, Williams GT, Sampson JR, Cheadle JP (2002) Biallelic germline mutations in MYH predispose to multiple colorectal adenoma and somatic G:C $\rightarrow$ T:A mutations. Hum Mol Genet 11: 2961-2967

Kane MF, Loda M, Gaida GM, Lipman J, Mishra R, Goldman H, Jessup JM, Kolodner R (1997) Methylation of the hMLH1 promoter correlates with lack of expression of hMLH1 in sporadic colon tumors and mismatch repair-defective human tumor cell lines. Cancer Res 57: 808-811
Kat A, Thilly WG, Fang WH, Longley MJ, Li GM, Modrich P (1993) An alkylation-tolerant, mutator human cell line is deficient in strand-specific mismatch repair. Proc Natl Acad Sci USA 90: $6424-6428$

Koi M, Umar A, Chauhan DP, Cherian SP, Carethers JM, Kunkel TA, Boland CR (1994) Human chromosome 3 corrects mismatch repair deficiency and microsatellite instability and reduces $N$-methyl- $N^{\prime}$-nitro$\mathrm{N}$-nitrosoguanidine tolerance in colon tumor cells with homozygous hMLH1 mutation. Cancer Res 54: 4308-4312

Leach FS, Nicolaides NC, Papadopoulos N, Liu B, Jen J, Parsons R, Peltomaki P, Sistonen P, Aaltonen LA, Nystrom-Lahti M, Guan XY, Zhang J, Meltzer PS, Yu JW, Kao FT, Chen DJ, Cerosaletti KM, Fournier R, Todd S, Lewis T, Leach RJ, Naylor SL, Weisssenbach J, Mecklin JP, Jarvinen H, Petersen GM, Hamilton SR, Green J, Jass J, Watson P, Lynch HT, Trent JM, de la Chapelle A, Kinzler K, Vogelstein B (1993) Mutations of a mutS homolog in hereditary nonpolyposis colorectal cancer. Cell 75: $1215-1225$

Lipton L, Halford SE, Johnson V, Novelli MR, Jones A, Cummings C, Barclay E, Sieber O, Sadat A, Bisgaard ML, Hodgson SV, Aaltonen LA, Thomas HJ, Tomlinson IP (2003) Carcinogenesis in MYH-associated polyposis follows a distinct genetic pathway. Cancer Res 63: 7595-7599

Loeb LA (1991) Mutator phenotype may be required for multistage carcinogenesis. Cancer Res 51: 3075-3079

Loeb LA (2001) A mutator phenotype in cancer. Cancer Res 61: 3230-3239

Luria SE, Delbruck M (1943) Mutations of bacteria from virus sensitivity to virus resistance. Genetics 28: $491-511$

Maher VM, Dorney DJ, Mendrala AL, Konze-Thomas B, McCormick JJ (1979) DNA excision-repair processes in human cells can eliminate the cytotoxic and mutagenic consequences of ultraviolet irradiation. Mutat Res 62: $311-323$

Nghiem Y, Cabrera M, Cupples CG, Miller JH (1988) The mutY gene: a mutator locus in Escherichia coli that generates G.C--T.A transversions. Proc Natl Acad Sci USA 85: 2709-2713

Nowell PC (1976) The clonal evolution of tumor cell populations. Science 194: $23-28$

Papadopoulos N, Nicolaides NC, Wei YF, Ruben SM, Carter KC, Rosen CA, Haseltine WA, Fleischmann RD, Fraser CM, Adams MD, Venter JC, Hamilton SR, Petersen GM, Watson P, Lynch HT, Peltomaki P, Mecklin JP, de la Chapelle A, Kinzler KW, Vogelstein B (1994) Mutation of a mutL homolog in hereditary colon cancer. Science 263: 1625-1629

Parker AR, O'Meally RN, Oliver DH, Hua L, Nelson WG, DeWeese TL, Eshleman JR (2002) 8-Hydroxyguanosine repair is defective in some microsatellite stable colorectal cancer cells. Cancer Res 62: 7230-7233

Sieber OM, Lipton L, Crabtree M, Heinimann K, Fidalgo P, Phillips RK, Bisgaard ML, Orntoft TF, Aaltonen LA, Hodgson SV, Thomas HJ, Tomlinson IP (2003) Multiple colorectal adenomas, classic adenomatous polyposis, and germ-line mutations in MYH. $N$ Engl J Med 348: 791 - 799

Veigl ML, Kasturi L, Olechnowicz J, Ma AH, Lutterbaugh JD, Periyasamy S, Li GM, Drummond J, Modrich PL, Sedwick WD, Markowitz SD (1998) Biallelic inactivation of hMLH1 by epigenetic gene silencing, a novel mechanism causing human MSI cancers. Proc Natl Acad Sci USA 95: $8698-8702$

Wang CY, Eshleman JR, Willson JK, Markowitz S (1995) Both transforming growth factor-beta and substrate release are inducers of apoptosis in a human colon adenoma cell line. Cancer Res 55: 5101-5105

Wang TL, Rago C, Silliman N, Ptak J, Markowitz S, Willson JK, Parmigiani G, Kinzler KW, Vogelstein B, Velculescu VE (2002) Prevalence of somatic alterations in the colorectal cancer cell genome. Proc Natl Acad Sci USA 99: $3076-3080$

Warren ST, Schultz RA, Chang CC, Wade MH, Trosko JE (1981) Elevated spontaneous mutation rate in Bloom syndrome fibroblasts. Proc Natl Acad Sci USA 78: 3133-3137

Willson JK, Bittner GN, Oberley TD, Meisner LF, Weese JL (1987) Cell culture of human colon adenomas and carcinomas. Cancer Res 47: $2704-2713$ 